\title{
HOW DOES CREDIT PORTFOLIO DIVERSIFICATION AFFECT BANKS' RETURN AND RISK? EVIDENCE FROM CHINESE LISTED COMMERCIAL BANKS
}

\author{
Yibing $\mathrm{CHEN}^{\mathrm{a}, \mathrm{b}}$, Yong $\mathrm{SHI}^{\mathrm{a}, \mathrm{c}}$, Xianhua $\mathrm{WEI}^{\mathrm{a}, \mathrm{b}}$, Lingling $\mathrm{ZHANG}^{\mathrm{a}, \mathrm{b}}$ \\ ${ }^{a}$ Research Centre on Fictitious Economy and Data Science, Chinese Academy of Sciences, \\ 100190 Beijing, China \\ ${ }^{\mathrm{b} S}$ chool of Management, University of Chinese Academy of Sciences, \\ 100190 Beijing, China \\ ${ }^{\circ}$ College of Information Science and Technology, University of Nebraska at Omaha, \\ 68182 Omaha, NE, USA
}

Received 27 September 2013; accepted 11 January 2014

\begin{abstract}
Does diversification of credit portfolio indeed lead to increased performance and reduced risk of banks as traditional portfolio theory suggests? This paper investigates empirically the effects of diversification on the Chinese banks' return and risk from the aspect of sector. Panel data on 16 Chinese listed commercial banks during the 2007-2011 period is used for the study. We construct a new diversification measure, taking systematic risk of different sectors into consideration by weighting them with their betas and compare the results with those of more conventional measure $\mathrm{HHI}$. We find that sectorial diversification is associated with reduced return and also decreased risk at the same time, which however, contradicts existing findings in developed countries such as Italy and Germany, and also in emerging economies such as Brazil and Argentina. Our analysis also provides important implication for regulators and policy makers of the banks in emerging markets.
\end{abstract}

Keywords: sectoral diversification, credit portfolio, return and risk, emerging markets, HHI, risk-adjusted $\mathrm{HHI}$.

Reference to this paper should be made as follows: Chen, Y.; Shi, Y.; Wei, X.; Zhang, L. 2014. How does credit portfolio diversification affect banks' return and risk? Evidence from Chinese listed commercial banks, Technological and Economic Development of Economy 20(2): 332-352.

JEL Classification: G11, G21, G28.

Corresponding author Yong Shi

E-mail:yshi@ucas.ac.cn 


\section{Introduction}

Recent years witnessed a new research trend of diversification effects on banks, which encourages regulators and banks to establish a comprehensive view of risk. Among the recent literatures, how to deal with dependency between different types of financial risks and delve how much diversification benefits can risk aggregation achieve have become a hot issue (Li et al. 2012, 2013).

The major role of banks within China is to provide loans to corporates and households. Does diversification among sectors of credit portfolio help banks to achieve reduced risk as traditional portfolio suggests? Does diversification indeed lead to increased performance of banks? This paper serves as a tentative answer to these questions by investigating empirically how credit portfolio diversification affects banks' return and risk in Chinese banking system from the aspect of sector.

In real world, we observe both diversification and concentration strategies adopted by banks. On one hand, several countries possess rules limiting a bank's exposure to a single borrower (Basel 1991), encouraging them to "put eggs in more than on basket". On the other hand, however, some banks decide to involve in sectors which they have expertise and enjoy comparative advantages. Subprime crisis, in the year 2008, which later lead to global financial crisis is partly due to too much exposures to real estate industry which is highly related to macro economy (Demyanyk, Van Hemert 2011). This crisis, caused by credit portfolio concentration, in return, hit the whole banking industry of US heavily. In the light of financial crisis, diversification versus concentration has become one of the most important issues to be discussed concerning financial stability.

Should banks diversify their loans or concentrate on those firms whose business they are familiar with? There are some research works on the relationship between diversification and performance of banks, however there is no consensus so far, because findings of different countries vary, with evidences supporting both opinions.

On one hand, traditional banking theory suggests that banks should diversify their loans to decrease credit risk, which is also in accordance with portfolio theory (Markowitz 1959). The view is due to asymmetric information, diversification reduces financial intermediation costs (Diamond 1984). In practice, Basel Committee on Banking Supervision (1991) reported that many banking crises in the last three decades were caused by concentration, indicating that risk is highly associated with concentration. Empirical studies in Argentina (Bebczuk, Galindo 2008), Japan (Sawada 2011), India (Pennathur et al. 2012), Pakistan (Afzal, Mirza 2012) South Asia (Dempsey et al. 2013) and Austria (Rossi et al. 2009) are in favor of this point of view. De Jonghe, Beck (2013) used a global sample over the period 2002 to 2011 for research and found that sectorial specialization increases volatility and systemic risk, while not leading to higher returns.

On the other hand, corporate finance theory states that firms would enjoy additional benefits resulting from reduced cost if they concentrate their activities on specific sectors which they have expertise in or are familiar with (Acharya et al. 2006). There is empirical evidence that specialized banks possess a higher monitoring quality than diversified banks, therefore yield lower loan loss provisions and higher profitability (Böve, Pfingsten 2008). 
In addition, the diversification strategy is less attractive because it also induces competition (Winton 1999). Empirical evidence can be found to support this argument in Italian banking sector (Acharya et al. 2006), German banking sector (Hayden et al. 2007), Brazilian banking sector (Tabak et al. 2011) and small European banks (Mercieca et al. 2007).

We summarize the existing empirical studies on this issue in Table 1. Region or country studied, sample period, type of diversification and main findings are listed respectively.

Table 1. Summary of recent researches on the impact of diversification on banks' return and risk

\begin{tabular}{|c|c|c|c|c|}
\hline $\begin{array}{l}\text { Region/country } \\
\text { studied }\end{array}$ & Authors & Period & $\begin{array}{c}\text { Type of } \\
\text { diversification }\end{array}$ & Main findings \\
\hline Germany & Kamp et al. (2005) & $1993-2002$ & $\begin{array}{l}\text { Economic } \\
\text { sectors }\end{array}$ & $\begin{array}{l}\text { Concentration increases } \\
\text { banks' return and } \\
\text { decreases LLP and NPL. }\end{array}$ \\
\hline Italy & $\begin{array}{l}\text { Acharya et al. } \\
\text { (2006) }\end{array}$ & $1993-1999$ & $\begin{array}{l}\text { Economic } \\
\text { sectors }\end{array}$ & $\begin{array}{l}\text { Concentration increases } \\
\text { returns and reduces } \\
\text { risks. }\end{array}$ \\
\hline US & $\begin{array}{l}\text { Stiroh, Rumble } \\
\text { (2006) }\end{array}$ & $1997-2002$ & $\begin{array}{l}\text { Sources of } \\
\text { income }\end{array}$ & $\begin{array}{l}\text { Diversification is positive } \\
\text { for bank performance; } \\
\text { the expansion to more } \\
\text { volatile activities, } \\
\text { however offset the } \\
\text { benefits. }\end{array}$ \\
\hline Europe & $\begin{array}{l}\text { Mercieca et al. } \\
(2007)\end{array}$ & $1997-2003$ & $\begin{array}{l}\text { Sources of } \\
\text { income }\end{array}$ & $\begin{array}{l}\text { No direct benefit of } \\
\text { diversification for small } \\
\text { banks. }\end{array}$ \\
\hline Germany & $\begin{array}{l}\text { Hayden et al. } \\
\text { (2007) }\end{array}$ & $1996-2002$ & $\begin{array}{l}\text { Economic } \\
\text { sectors; } \\
\text { geographical }\end{array}$ & $\begin{array}{l}\text { Diversification is } \\
\text { detrimental to banks' } \\
\text { return. High-risk banks } \\
\text { are less affected by } \\
\text { diversification. }\end{array}$ \\
\hline Argentina & $\begin{array}{l}\text { Bebczuk, Galindo } \\
\text { (2008) }\end{array}$ & 1999-2004 & $\begin{array}{l}\text { Economic } \\
\text { sectors }\end{array}$ & $\begin{array}{l}\text { There is a positive effect } \\
\text { of diversification on } \\
\text { profitability and risk } \\
\text { mitigation. }\end{array}$ \\
\hline China & $\begin{array}{l}\text { Berger et al. } \\
(2010)\end{array}$ & 1996-2006 & $\begin{array}{l}\text { Geographical, } \\
\text { loans, deposit } \\
\text { and assets }\end{array}$ & $\begin{array}{l}\text { Diversification reduces } \\
\text { profits and increases } \\
\text { costs. }\end{array}$ \\
\hline Brazil & Tabak et al. (2011) & $2003-2009$ & $\begin{array}{l}\text { Economic } \\
\text { sectors }\end{array}$ & $\begin{array}{l}\text { Concentration improves } \\
\text { return performance and } \\
\text { reduces default risk. }\end{array}$ \\
\hline Japan & Sawada (2011) & 1999-2011 & $\begin{array}{l}\text { Sources of } \\
\text { income }\end{array}$ & $\begin{array}{l}\text { Positive effect of revenue } \\
\text { diversification on } \\
\text { franchise value, and } \\
\text { no strong evidence of } \\
\text { reducing risk. }\end{array}$ \\
\hline India & $\begin{array}{l}\text { Pennathur et al. } \\
\text { (2012) }\end{array}$ & 2001-2009 & $\begin{array}{l}\text { Sources of } \\
\text { income }\end{array}$ & $\begin{array}{l}\text { Diversification benefits } \\
\text { public sector banks with } \\
\text { reduced risk. }\end{array}$ \\
\hline
\end{tabular}


Continued Table 1

\begin{tabular}{|c|c|c|c|c|}
\hline $\begin{array}{l}\text { Region/country } \\
\text { studied }\end{array}$ & Authors & Period & $\begin{array}{c}\text { Type of } \\
\text { diversification }\end{array}$ & Main findings \\
\hline Pakistan & $\begin{array}{l}\text { Afzal, Mirza } \\
(2012)\end{array}$ & 2004-2009 & $\begin{array}{l}\text { Economic } \\
\text { sectors }\end{array}$ & $\begin{array}{l}\text { Diversification is } \\
\text { considered as a relevant } \\
\text { tool for risk mitigation } \\
\text { as it is significantly } \\
\text { related to market-based } \\
\text { measure of risk. }\end{array}$ \\
\hline South Asia & $\begin{array}{l}\text { Dempsey et al. } \\
\text { (2013) }\end{array}$ & 1999-2010 & $\begin{array}{l}\text { Sources of } \\
\text { income }\end{array}$ & $\begin{array}{l}\text { Income diversification } \\
\text { associates positively with } \\
\text { market to book value } \\
\text { and negatively with } \\
\text { return volatility. }\end{array}$ \\
\hline Global samples & $\begin{array}{l}\text { De Jonghe, Beck } \\
\text { (2013) }\end{array}$ & $2002-2011$ & $\begin{array}{l}\text { Economic } \\
\text { sectors }\end{array}$ & $\begin{array}{l}\text { Sectoral specialization } \\
\text { increases volatility while } \\
\text { does not lead to higher } \\
\text { returns. }\end{array}$ \\
\hline Global samples & $\begin{array}{l}\text { García-Herrero, } \\
\text { Vázquez (2013) }\end{array}$ & 1995-2004 & Geographical & $\begin{array}{l}\text { Returns were reduced by } \\
\text { concentration of bank } \\
\text { subsidiaries in specific } \\
\text { geographical regions. }\end{array}$ \\
\hline
\end{tabular}

However, the existing literatures on diversification versus concentration are heavily concentrated in US and Europe markets. Only few works were about developing markets including Brazil and Argentina. As one of the biggest and fastest-growing emerging economies in the world, China has been playing an utmost important role in world economy. To the best of our knowledge, however, only Berger, Hasan and Zhou investigated this issue in Chinese banking sector from the geographical, loans, deposit and assets diversification leaving the field much unexamined (Berger et al. 2010).

Chinese banks had been heavily influenced by policy makers and did not pay attention to sectorial diversification in the past. Each bank had its own position in the banking system, and produced its expertise on some certain sectors. They were often required by policy makers to direct their loans (such as policy loans) to the sectors that they had expertise before 1990s. Take Big Four banks of China as examples. Bank of China (BOC) was advised to concentrate on the foreign exchange and currency businesses. Agricultural Bank of China (ABC) was instructed to lend most of the loans to agricultural sector, especially in rural areas. Industrial and Commercial Bank of China (ICBC) was required to provide majority of its lending to manufacturing and commercial sectors. China Construction Bank (CCB) was instructed to lend heavily to real estate and construction materials industries (Fu, Heffernan 2009; Hasan et al. 2009; Lin, Zhang 2009).

Such restrictions gradually disappeared in the latter half of the 1990s, and now most of the banks are involved in all the industries including farming, forestry, husbandry and fishing; mining; manufacturing, production and supply of electric power, gas and water; construction; transportation and warehousing; information technology; wholesale and retail trade; finance and insurance; real estate; social service (including science, education and health); communication 
and culture, etc. Question arises that whether they should diversify across the industries or specialize in one or few sectors? Will concentration on real estate bring higher risk just as US?

The primary goal of this paper is to analyze how credit portfolio sectorial concentration affects Chinese bank profitability and risk, which is different from previous work of Chinese banking system focusing on overall diversification (Berger et al. 2010). This work has direct consequences to financial regulation and policy makers in this largest emerging economy, for the reason that, in China, regulators and policy makers can incentivize or set limit on exposures of certain sectors to ensure Chinese financial stability.

An important contribution of our work is that we do not only consider sectorial concentration, but also systematic risk of sectors themselves. Concentration does associate with risk, but concentration on those sectors that are more volatile and closely related with economic upturns and downturns brings more risk. To address this problem, we construct a new diversification measure, taking systematic risk of different sectors into consideration by weighting them with their betas.

The remainder of the paper is organized as follows. Section 1 introduces our methodology, defining the variables of interest and the empirical models. Our data will be described in details in Section 2. Section 3 displays our empirical results and the final section concludes the paper.

\section{Methodology}

\subsection{Diversification measures}

Previous research works applied several commonly-used traditional diversification measures including Hirschman-Herfindhl (HHI) (Berger et al. 2010; Hayden et al. 2007) and the Shannon Entropy (SE) (Kamp et al. 2005; Tabak et al. 2011). Some of the papers also used distance-based diversification measures to compare the differences between credit portfolio composition and a benchmark. In most of the cases, the industry composition of the economy's market portfolio is a benchmark for diversification. Distance-based diversification measures therefore take the differences in sizes of each sector into consideration (Pfingsten, Rudolph 2002; Tabak et al. 2011).

It's important to highlight that the purpose of our work is to examine whether the sectorial composition in the banks' credit portfolios affect the banks' return and risk. Sectorial composition means the banks' relative exposures to certain sectors. Before we introduce our proxies of diversification which are used in the paper at length, we briefly illustrate why we do not consider distance-based diversification measures.

The particular circumstance in China is that sector classification and definition is slightly different between that in economic activity ${ }^{1}$ and in security markets ${ }^{2}$. For example, K. Social service in the 13-sector classification in security markets covers M. Science, P. Education,

20 sectors in total, set by National Bureau of Statistics of China. See Industry Classification of National Economy, GB/T 4754-2011.

213 sectors in total, set by China Securities Regulatory Commission (CSRC). See Industry Classification Guidance for Listed Companies, CSRC Public Announcement, 2012, No. 31. 
Q Health, etc. in 20-sector classification of economic activity ${ }^{3}$. However, most of the listed commercial banks report their lending according to 13-sector classification set by CSRC respectively. Therefore, it's difficult to distinguish the difference between their sectorial composition of credit portfolio and the macroeconomic market portfolio of the whole country.

Due to the above reason, we choose Herfindhl-Hirschman Index as the basic measure of diversification, and also construct a new one based on it, taking systematic risk of each sector into consideration.

\subsubsection{Hirschman-Herfindhl Index (HHI)}

Hirschman-Herfindhl Index (HHI) is a commonly used accepted measure of market concentration (Rhoades 1993). It assumes perfect diversification as equal exposure to every sector.

Before we calculate the diversification measure, for each bank, relative exposure $x_{i t}$ of each sector $i$ at time $t$ is defined as its nominal exposure $e x_{i t}$ divided by the total exposure $\sum_{k=1}^{N} e x_{k t}$ :

$$
x_{i t}=\frac{e x_{i t}}{\sum_{k=1}^{N} e x_{k t}} .
$$

$\mathrm{HHI}$ is the sum of the squares of the relative exposures. And thus for each individual bank, it is defined as:

$$
H H I_{t}=\sum_{i=1}^{N} x_{i t}^{2}
$$

where $N$ is the total number of sectors the banks provide their lending to. The lower and upper bound of HHI is $\frac{1}{N}$ and 1 , representing a perfect diversified and a perfect focused portfolio respectively. The higher HHI value, the less is the diversification of the bank.

\subsubsection{Risk-adjusted HHI}

Traditional HHI equals relative exposure of every sector; however, sector itself has different vulnerability as a response to the whole economy's up and down. Lessons learned from banking crises of the 1980s and early 1990s taught us that banks should not exposure too much to only few sectors (FDIC 2007). Subprime crisis was partly due to too much exposure to real estate industry which has especially high correlations with macro economy (Demyanyk, Van Hemert 2011). To address the risk that a sector has high correlation with the macro economy, we introduce systematic risk of each sector in diversification measure. That is to weight more on relative exposures of the offensive sectors than these of the defensive sectors, rather than equal them in traditional HHI.

Systematic risk of one sector defined in this paper is much in line with the concept in economics and finance. Systematic risk is vulnerability to events which affect aggregate outcomes such as broad market returns, rather than individual return of a firm or an industry. It cannot be eliminated through diversification in a portfolio. In William Sharp's capital asset pricing

3 Details of the 20-sector classification is provided upon request, and 13-sector classification is described in subsection 2.2. 
model, the important concept to evaluate an asset's exposure to systematic risk is beta. It is an indicator of an asset's vulnerability to systematic risk, and indicates the degree to which an asset's expected return is correlated with boarder market return (Sharpe 1963, 1964).

In our paper, we replace an asset with a sector in Sharp's framework. Sector beta is used to measure to which extent a sector move together with the entire market. Then we introduce sector beta as weight of relative exposure of each sector respectively to construct our new diversification measure.

Risk-adjusted HHI for each bank at time $t$ as follows:

$$
\text { risk-adjusted } H H I_{t}=\sum_{i=1}^{N} \beta_{i t} x_{i t}^{2} .
$$

In Eq. (3), $\beta_{i t}$ reflects systematic risk of each sector $i$ at time $t$, defined as the covariance between market return and sector return $\operatorname{cov}\left(\mathrm{R}_{M t}, \mathrm{R}_{i t}\right)$ divided by the variance of market return $\sigma_{R_{M t}}^{2}$, as with Sharp's definition of beta.

$$
\beta_{i t}=\frac{\operatorname{cov}\left(\mathrm{R}_{M t}, \mathrm{R}_{i t}\right)}{\sigma_{R_{M t}}^{2}} .
$$

The higher risk-adjusted HHI value means not only the bank's credit portfolio is more concentrated, but also focused too much on the sectors with higher systematic risk.

\subsection{Dependent variables}

In this part, we briefly introduce the dependent variables and other control variables we use in our regression models.

\subsubsection{Return performance measures}

- Return on assets (ROA): measured as the ratio of net income to total assets;

- Return on Equity (ROE): measured as the ratio of net income to equity. The measure is to describe the return performance of the bank from the perspective of stockholders;

- We use both the measures for robustness check.

\subsubsection{Risk Measure}

- Nonperforming loans: we evaluate the banks' monitoring effectiveness. The variable is interpreted as an ex post measure of the actual losses from lending activity, and easy to be found in the banks' annual reports.

\subsection{Other control variables}

We control for characteristics that are commonly used as control variables in similar studies as (Acharya et al. 2006; Berger et al. 2010; Hayden et al. 2007). Control variables in our paper are: asset, loan-to-deposit ratio and equity ratio to describe a bank from the three important aspects - size, liquidity and capital structure. 
- Asset: we use the continuous variable to measure the size of the bank as most of the previous literatures did. This control variable is to capture size-related influences that stem from differences in size among banks, and to control for the well-known size effect (Dempsey et al. 2013). In our regression analysis, squared term $\ln ^{2}$ (asset) along with $\ln ($ asset $)$ are also introduced to capture for the potential nonlinear relationship between size and risk when the linear relationship is not significant.

- Loan-to-deposit ratio: The control variable is defined as total loan divided by total deposit. It is a commonly used statistic for assessing a bank's liquidity. If the ratio is too high, it means that banks might not have enough liquidity to cover any unforeseen fund requirements; if the ratio is too low, banks may not be earning as much as they could be. Therefore this ratio has the potential impact on banks' return and risk that should be controlled when doing regressions.

- Equity ratio: This control variable is defined as equity divided by the total assets, reflecting the capital structure of the bank. The reciprocal of equity ratio is the well-known equity multiplier which is associated closely with financial risk. Equity multiplier is also used to calculate return on equity in DuPont formula for financial analysis. Therefore, this variable is used mainly to control the influence of capital structure on banks' return and risk.

\subsection{Model specification}

\subsubsection{The relationship between bank returns and credit portfolio diversification}

The basic question in this study is whether loan sectorial diversification yields higher returns. We deal with this issue by regressing returns on diversification measures, while controlling other important variables in the following equation.

$$
\text { return }_{k t}=\beta_{0}+\beta_{1} \cdot \text { diversification }_{k t}+\gamma \cdot V_{k t}+\varepsilon_{k t},
$$

where return $k t$ is the return of bank $k$ at time $t$ measured by ROA and also ROE. $V_{k t}$ is a vector of control variables including asset, loan-to-deposit ratio and equity ratio. diversification ${ }_{k t}$ is the variable we are interested in, representing separately $\mathrm{HHI}$ and risk-adjusted $\mathrm{HHI}$ explained in the previous subsection. Finally, $\varepsilon_{k t}$ is the residual value.

If $\beta_{1}>0$, concentration seems to be more advantageous than diversification from the aspect of return. Otherwise, $\beta_{1}<0$ means that diversification across sectors yields higher return.

In addition, we also test the nonlinear relationship between credit loan diversification and banks' return by introducing squared term diversification $n_{k t}^{2}$ into the regression.

$$
\text { return }_{k t}=\beta_{0}+\beta_{1} \cdot \text { diversification }_{k t}+\beta_{2} \cdot \text { diversification }_{k t}^{2}+\gamma \cdot V_{k t}+\varepsilon_{k t} \text {. }
$$

If the regression model is significant, it seems to suggest that there exists U-shaped or reversed U-shaped relationship between diversification and banks' return. 


\subsubsection{The impact of credit portfolio diversification on bank risk}

This topic is to test how loan sectorial diversification impacts risk. We regress risk measure on diversification measures in the following equation. Asset, loan-to-deposit ratio and equity ratio are included in the regression as control variables.

$$
\text { risk }_{k t}=\beta_{0}+\beta_{1} \cdot \text { diversification }_{k t}+\gamma \cdot V_{k t}+\varepsilon_{k t},
$$

where risk $k t$ is the risk of bank $k$ at time $t$ measured by nonperforming loans. Since we evaluate the banks' monitoring effectiveness, absolute value of nonperforming loans is used. diversification $_{k t}$ is separately HHI and risk-adjusted HHI explained in the previous subsection. Finally, $\varepsilon_{k t}$ is the residual value.

In our regression analysis, squared term $\ln ^{2}$ (asset) along with $\ln ($ asset) are also introduced to capture for the potential nonlinear relationship between size and risk when the linear relationship is not significant.

If $\beta_{1}>0$, concentration seems to be less attractive than diversification since risk is higher. Otherwise, $\beta_{1}<0$ means that diversification across sectors brings more risk.

In addition, we also test the potential nonlinear relationship such as $U$-shaped or reversed U-shaped between credit loan diversification and banks' return by introducing squared term diversification $_{k t}^{2}$ into the regression.

$$
\text { risk }_{k t}=\beta_{0}+\beta_{1} \cdot \text { diversification }_{k t}+\beta_{2} \cdot \text { diversification }_{k t}^{2}+\gamma \cdot V_{k t}+\varepsilon_{k t} .
$$

\section{Data}

\subsection{Sample and data source}

In China, there are 16 listed commercial banks in all. These banks take a large asset proportion of the whole banking sector ${ }^{4}$. Our sample includes panel data of all the 16 Chinese listed commercial banks in 2007-2011 period, 80 observations in total. The 16 commercial banks are: Industrial and Commercial Bank of China (ICBC), Agricultural Bank of China (ABC), Bank of China (BOC), China Construction Bank (CCB), Bank of Communications (BOCOM), China Merchants Bank (CMB), Shanghai Pudong Development Bank (SPDB), China Minsheng Banking Corporation (CMBC), China Citic Bank (CITIC), China Everbright Bank (CEBB), Industrial Bank Corporation (IBC), Huaxia Bank (HXB), Shenzhen Development Bank (SDB, now is merged with Pingan Bank), Bank of Beijing (BBJ), Bank of Nanjing (BNJ), and Bank of Ningbo (BNB) ${ }^{5}$.

These commercial banks began to adopt new accounting standards in 2007. Besides, in the period of 2007-2011, Chinese banking sector was developing stably without significant

\footnotetext{
4 The Big Five banks including ICBC, ABC, BOC, CCB and BOCOM take a percentage of $47.3 \%$ assets of the whole banking sector in 2011. See 2011 Annual Report of China Banking Regulatory Commission (CBRC). It can be estimated that the 16 banks included in the sample take at least $63.1 \%$ of the entire banking industry using asset data acquired.

5 There are missing values of equity in $\mathrm{ABC}$ in 2007 and 2008. We calculate equity of 2008 according to equity ratio of 2008 reported in 2009 annual report.
} 
reforms. Therefore, our choice of the time period helps to examine the stable relationship between diversification and banks' return and risk.

Sector exposures of every listed commercial bank of the five years are from their annual reports. They direct their loans to the following sectors: farming, forestry, husbandry and fishing; mining; manufacturing, production and supply of electric power, gas and water; construction; transportation and warehousing; information technology; wholesale and retail trade; finance and insurance; real estate; social service (including science, education and health); communication and culture, etc. Their classification of sectors is mainly in accordance with the 13-sector classification standard set by CSRC; therefore, we only adjust some of their reported sector loan exposures to ensure consistency between the 16 banks and also the 13-sector classification standard.

Return performance measures and risk measure is from Wind database ${ }^{6}$. We also double check them with those on the banks' annual reports.

\subsection{HHI and risk-adjusted HHI calculation}

Definition and classification of sectors in the 16 listed commercial banks' loan exposures reports show slight differences in some sectors. We adjust the inconsistent ones to ensure that we can compare the calculated HHI between the banks and also between the different years. 13-sector classification specified by CSRC is listed in Table 2.

Table 2. 13-sector classification specified by CSRC

\begin{tabular}{cl}
\hline Sector code & \multicolumn{1}{c}{ Description } \\
\hline A & farming, forestry, husbandry and fishing \\
\hline B & mining \\
\hline C & manufacturing \\
\hline D & production and supply of electric power, gas and water \\
\hline E & construction \\
\hline F & transportation and warehousing \\
\hline G & information technology \\
\hline H & wholesale and retail trade \\
\hline I & finance and insurance \\
\hline J & real estate \\
\hline K & social service \\
\hline L & communication and culture \\
\hline M & comprehensive industry
\end{tabular}

The 16 listed banks all reported their exposures in the following sectors: $\mathrm{B}, \mathrm{C}, \mathrm{D}, \mathrm{E}, \mathrm{F}, \mathrm{H}$, and J. However, some of the banks classified one, some or all of the Sector A, G, I, M into "others", and the rest banks reported them separately if they provided loans to any of Sector A, G, I, M. Besides, some banks had their own sector "science, education, culture and health",

6 Wind database is a widely used service provider of financial data in China. 
"public service" in their reporting, while other confirmed to 13-classification regulation in which "communication and culture" is an independent sector. To overcome the inconsistency, we adjust our classification standard shown as Table 3.

Table 3. Adjusted sector classification standard

\begin{tabular}{clc}
\hline No & \multicolumn{1}{c}{ Description } & Sector code \\
\hline I1 & mining & $\mathrm{B}$ \\
\hline I2 & manufacturing & $\mathrm{C}$ \\
\hline I3 & production and supply of electric power, gas and water & $\mathrm{D}$ \\
\hline I4 & construction & $\mathrm{E}$ \\
\hline I5 & transportation and warehousing & $\mathrm{F}$ \\
\hline I6 & wholesale and retail trade & $\mathrm{H}$ \\
\hline I7 & real estate & $\mathrm{J}$ \\
\hline I8 & $\begin{array}{l}\text { social services: science, education, culture and health leasing } \\
\text { and business service communication and publication }\end{array}$ & $\mathrm{A}, \mathrm{G}, \mathrm{I}, \mathrm{M}$ \\
\hline I9 & $\begin{array}{l}\text { others: (any, some or all of the following) farming, forestry, } \\
\text { husbandry and fishing information technology finance } \\
\text { and insurance comprehensive industry }\end{array}$ & \\
\hline
\end{tabular}

The most important issue in calculation of risk-adjusted HHI is to estimate sector betas. First, we choose the right proxy of market return. Cross correlations between Shanghai index (SH), Shenzhen index (SZ) and Hushen 300 index (HS 300) are calculated. Since they are highly positive related with correlation coefficient higher than 0.85 , we choose return rate of Shanghai composite index as proxy of market return because it covers a wider range thus better describe the market. Shanghai composite index is available in Wind database, which is in daily frequency.

Then, we prepare return rate of all the sectors. Wind database provides indices of all the 13 sectors in accordance with CSRC standard, all in daily frequency. To eliminate unnecessary volatility, we calculate weekly return of market and all the sectors by doing logarithmic transformation of weekly closing index series respectively.

$$
\beta_{i t}=\frac{\operatorname{cov}\left(\mathrm{R}_{M t}, \mathrm{R}_{i t}\right)}{\sigma_{R_{M t}}^{2}} \text { is used to estimate sector betas. Note that we list our results according to }
$$

CSRC 13-sector classification. When we introduce the sector betas to calculate risk-adjusted HHI, we do adjustment according to our new classification standard.

Original beta values of Sector B, C, D, E, F, H, and J is used. Average of Sector K and L's betas is replaced with I8 in our new standard. For I9, we calculate beta of each bank according to the sectors included in "others" category (one, some or all of Sector A, G, I, M) by averaging their betas. For example, we classify Sector I and M for BOC into I9 "others", average beta of Sector I and M is used to replace I9's beta. Table 4 presents the calculated betas of each sector of the five years. 
Table 4. Sector betas in 2007-2011 period

\begin{tabular}{cccccc}
\hline & 2007 & 2008 & 2009 & 2010 & 2011 \\
\hline $\mathrm{A}$ & 0.885 & 1.074 & 1.042 & 0.845 & 1.148 \\
\hline $\mathrm{B}$ & 1.117 & 1.092 & 1.238 & 1.358 & 0.769 \\
\hline $\mathrm{C}$ & 1.017 & 1.055 & 0.998 & 0.966 & 1.251 \\
\hline $\mathrm{D}$ & 0.971 & 0.888 & 0.881 & 0.812 & 1.009 \\
\hline $\mathrm{E}$ & 1.130 & 1.067 & 1.008 & 0.914 & 1.238 \\
\hline $\mathrm{F}$ & 0.921 & 1.075 & 1.086 & 1.069 & 1.047 \\
\hline $\mathrm{G}$ & 0.784 & 0.952 & 0.918 & 0.899 & 1.128 \\
\hline $\mathrm{H}$ & 1.086 & 0.976 & 0.995 & 0.825 & 1.175 \\
\hline $\mathrm{I}$ & 1.112 & 1.166 & 1.065 & 0.929 & 0.855 \\
\hline $\mathrm{J}$ & 1.213 & 1.232 & 1.421 & 1.068 & 1.269 \\
\hline $\mathrm{K}$ & 0.976 & 1.166 & 1.145 & 0.848 & 1.254 \\
\hline $\mathrm{L}$ & 0.867 & 0.961 & 0.950 & 0.788 & 1.377 \\
\hline $\mathrm{M}$ & 1.121 & 1.078 & 1.112 & 0.970 & 1.387 \\
\hline
\end{tabular}

\subsection{Summary statistics}

Table 5 presents the summary statistics of the variables that we use in our models specified. The most important issue in our study, by analyzing the mean and standard deviation of the concentration measure, is that Chinese banks' credit portfolios seem to be well diversified.

Table 5. Summary statistics of the variables

\begin{tabular}{|c|c|c|c|c|c|c|c|c|}
\hline & 焉 &  & 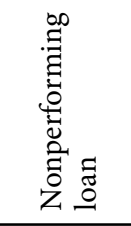 & ৫্ & 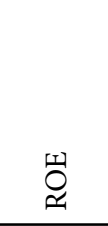 & 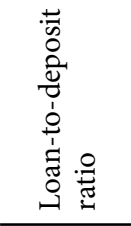 & 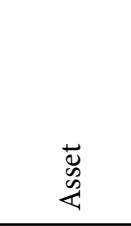 & 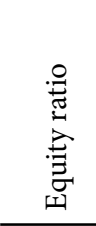 \\
\hline Mean & 0.187 & 0.197 & 56657.36 & 1.079 & 19.904 & 67.853 & 3388097 & 5.837 \\
\hline Median & 0.173 & 0.183 & 13993.95 & 1.105 & 19.400 & 69.682 & 1527874 & 5.772 \\
\hline Maximum & 0.372 & 0.381 & 303020 & 1.720 & 41.120 & 83.784 & 15476868 & 13.071 \\
\hline Minimum & 0.145 & 0.144 & 271.839 & 0.150 & 4.180 & 50.840 & 75510.77 & 2.204 \\
\hline Std. Dev. & 0.039 & 0.043 & 80658.06 & 0.261 & 5.144 & 6.790 & 3963708 & 1.841 \\
\hline Skewness & 2.312 & 1.868 & 1.472 & -0.810 & 1.036 & -0.175 & 1.370 & 1.306 \\
\hline Kurtosis & 9.558 & 7.266 & 3.789 & 4.602 & 6.956 & 2.588 & 3.604 & 6.367 \\
\hline Jarque-Bera & 214.641 & 107.2 & 30.971 & 17.302 & 65.636 & 0.974 & 26.233 & 59.759 \\
\hline Probability & 0 & 0 & 0 & 0.00018 & 0 & 0.614578 & 0.000002 & 0 \\
\hline Observations & 80 & 80 & 80 & 80 & 79 & 80 & 80 & 79 \\
\hline $\begin{array}{l}\text { Cross } \\
\text { sections }\end{array}$ & 16 & 16 & 16 & 16 & 16 & 16 & 16 & 16 \\
\hline
\end{tabular}


We compare average $\mathrm{HHI}$ of Chinese banking sector with the main findings of the previous study. In general it is more diversified than Italians' whose average $\mathrm{HHI}$ is 0.237 (Acharya et al. 2006), Irish's (McElligott, Stuart 2007) and German's (Hayden et al. 2007) in which HHI both equal 0.291. For emerging markets, Brazilians' and Argentines' are also more concentrated than Chinese's with HHI 0.316 (Tabak et al. 2011) and 0.55 (Bebczuk, Galindo 2008) respectively.

Table 6 depicts the cross correlations of the variables we are interested in with asset.

Table 6. Correlations of HHI, risk-adjusted HHI and asset

\begin{tabular}{lccc}
\hline & HHI & Risk-adjusted HHI & Asset \\
\hline HHI & 1 & & \\
\hline Risk-adjusted HHI & 0.895 & 1 & \\
\hline Asset & -0.408 & -0.358 & 1 \\
\hline
\end{tabular}

This provides evidence that a not absolutely pronounced correlation exists between $\mathrm{HHI}$ and risk-adjusted HHI, suggesting that the effects of both on return performance and risk may be at least slightly different. So it is necessary to observe the effects of both on return and risk. Besides, there is an obvious negative correlation between credit loan concentration and the size of bank. A possible reason to explain is that larger banks have accesses to more resources, possess more adequate capital and have deeper understanding in lending to several sectors.

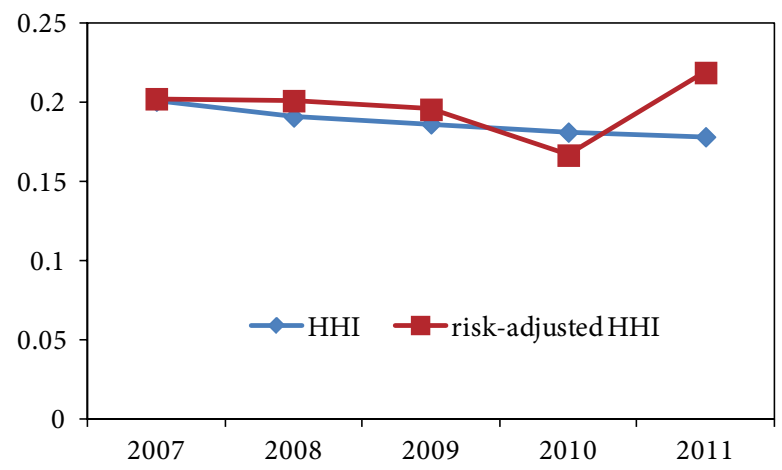

Fig. 1. Tendency of HHI and risk-adjusted HHI in 2007-2011

Figure 1 shows the tendency of average HHI and risk-adjusted HHI of the 16 banks in the five years. It is easy to find that there is a decreasing tendency of sectoral concentration as HHI reduces with time passes, which seems to indicate that credit portfolios are less concentrated. However, risk-adjusted HHI grows sharply in 2011, suggesting that more exposures to sectors with higher systematic risk such as real estate, manufacturing and construction. This may also result from increased systematic risk of these sectors at the same time. An increased risk-adjusted HHI may be a sign of higher risk resulting in more nonperforming loan, but it cannot be captured by traditional measure HHI. 


\section{Empirical results}

We present the results of our empirical regression models in this section. In the first subsection, we examine the effect of credit portfolio diversification on banks' return performance. In the second subsection, we analyze the effects of diversification on risk.

Panel data models are used to analyze the two issues. We test the presence of unit root for the variables including those we are interested and control variables, but they reject unit root in all cases. Our sample includes all the Chinese listed commercial banks. So it is safe for us to choose fixed effect models for regressions. We also apply Hausman test for all the models to validate our choice.

\subsection{The relationship between bank returns and credit portfolio diversification}

We try to investigate the effects of credit portfolio diversification measured by HHI and risk-adjusted $\mathrm{HHI}$ on ROA and then ROE, respectively, while controlling the bank's size, the equity ratio and the loan-to-deposit ratio.

To capture the potential nonlinear relationship between sectorial diversification and return performance, we also estimate equation with squared term of HHI and risk-adjusted HHI.

Table 7 presents the results of regression model Eq. (5) and Eq. (6).

In the specification Eq. (5), the coefficients for risk-adjusted HHI are positive and significant at $5 \%$ level for return performance measured both by ROA and ROE. HHI is also positive and significant at $10 \%$ level when ROE is the dependent variable. Risk-adjusted HHI is better to capture the relation between credit diversification and return measure when systematic risk is taken into consideration.

However, in estimation of Eq. (6), both the original and squared term of HHI and risk-adjusted HHI reject the significance, while control variables remain significant. This suggests that there is no nonlinear relationship between diversification and return performance.

The above results give evidence that concentration seems to positively influence banks' return but not in a nonlinear form, indicating that on average, focused credit portfolio to fewer sectors yields higher profits than diversified portfolio. One of the most possible reason is that diversification may result in higher monitoring costs, which reduces the overall profits (Acharya et al. 2006). Banks may have an expertise on some of the sectors, but not all. Thus involving more sectors means more costly to monitor.

The three control variables: the bank's size, the equity ratio and the loan-to-deposit ratio are all significant indicating that they indeed have the impact on return performance.

The coefficients of the bank's size remain positive and strongly significant in all the 8 models, which tends to suggest that larger banks have higher return performance than smaller banks. In addition, the coefficients of equity ratio are significantly positive in ROA estimations and significantly negative in ROE estimations. This indicates that an increase of equity ratio, which changes the capital structure, helps to achieve higher asset return but have a negative effect in the management of equity. This is also the case in Brazil, another emerging country, agreed by the previous literatures (Tabak et al. 2011; Tecles, Tabak 2010). 


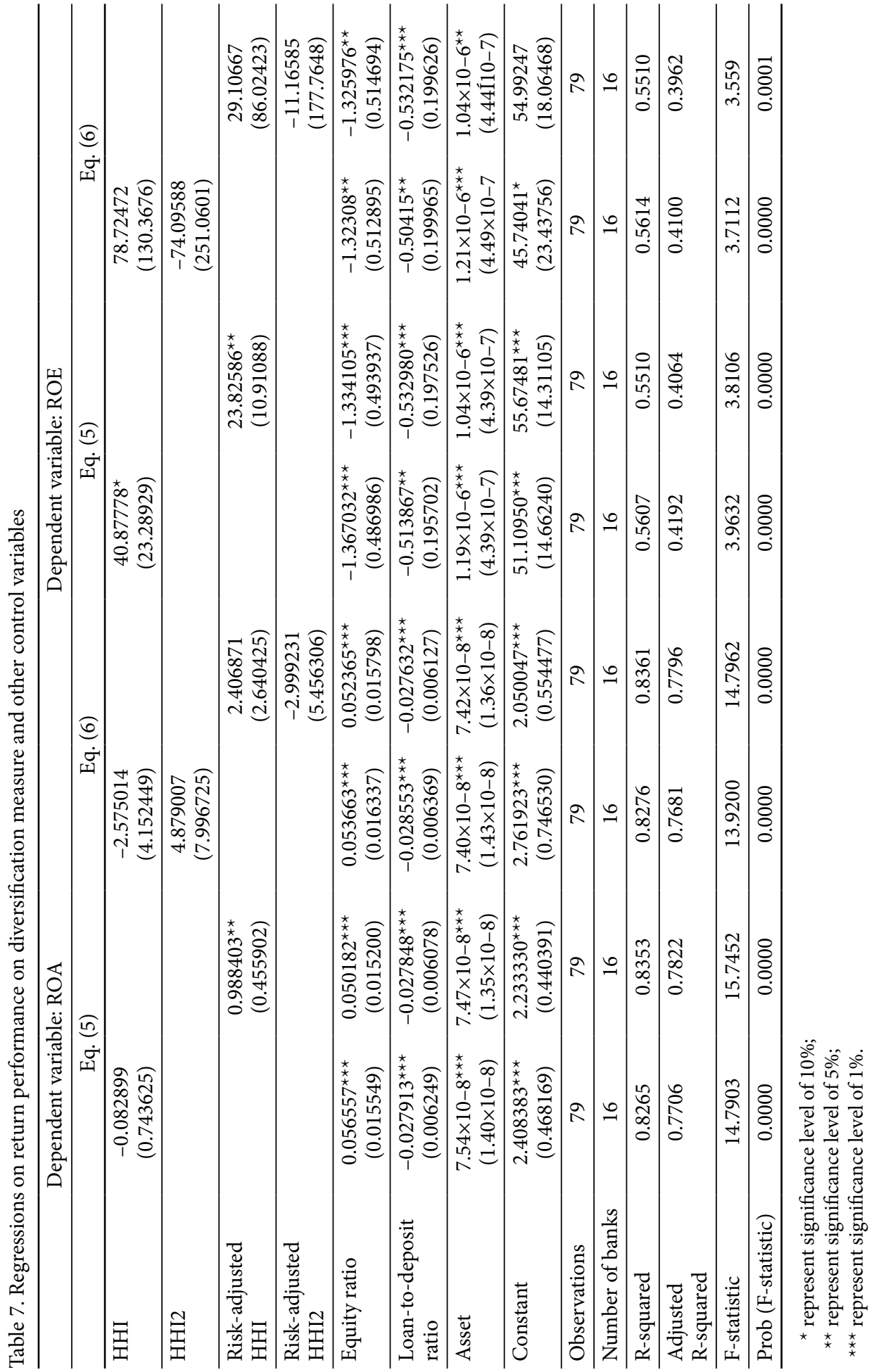




\subsection{The impact of credit portfolio diversification on bank risk}

In this part, our goal is to evaluate the effects of credit portfolio diversification measured by $\mathrm{HHI}$ and risk-adjusted HHI on banks' risk, proxied by nonperforming loan (in absolute value), while controlling the bank's size, the equity ratio and the loan-to-deposit ratio. Note that we also try to introduce squared term $\ln ^{2}$ (asset) along with $\ln$ (asset) to describe the potential nonlinear relationship between size and risk when the linear relationship is not significant.

To capture the potential nonlinear relationship between sectorial diversification and risk, we also estimate equation with squared term of $\mathrm{HHI}$ and risk-adjusted HHI.

Table 8 presents the results of regression model Eq. (7) and Eq. (8).

Regarding the portfolio diversification measure, in the specification Eq. (7), the coefficients for risk-adjusted HHI are positive and significant at 5\% level to bank's risk both when bank's size is proxied by asset absolute value and by squared term $\ln ^{2}$ (asset) along with $\ln ($ asset). $\mathrm{HHI}$ is also positive and significant at $10 \%$ level when bank's size is described by $\ln ^{2}$ (asset) and $\ln ($ asset $)$.

However, in estimation of Eq. (8), significance of nonlinear form of HHI and risk-adjusted HHI are both rejected. This suggests that there is no significant nonlinear relationship between diversification and risk measure.

These results provide evidence that portfolio concentration significantly positively related to the bank's risk, which is in agreement with the idea of Diamond (1984), stating that the expansion of banks' credit lines to new sectors reduced the bank's probability of default. Moreover, concentrated credit portfolio will be vulnerable to economic downturns since they only expose themselves to few sectors. The bank risk would be higher if the few sectors which the bank exposes to have higher systematic risks, which can be explained by our regression results when risk-adjusted $\mathrm{HHI}$ is used as diversification measure.

But our findings contradict the conclusions that concentration reduces risk from other existing research works in both developed and developing countries (Acharya et al. 2006; Kamp et al. 2005; Tabak et al. 2011).

It can be observed that variable asset itself is not significant in all the four regression models. But when we introduce squared term $\ln ^{2}$ (asset) and $\ln ($ asset $)$ to describe bank's size, their coefficients become significant at $1 \%$ level, indicating that there exists nonlinear relationship (a reversed $U$ shape with great probability between bank's size and risk. To investigate this issue in detail, the axis of symmetry is $\ln ($ asset $) \approx 13$, which means that if asset $\geq e^{13}=442413$, larger banks will face less risks resulting from monitoring efficiency possibly. Among the samples, only the assets of Bank of Nanjing, and Bank of Ningbo during the five years are less than the threshold: 442413. That means, for majority of the listed commercial banks, larger banks are less exposed to risk. 


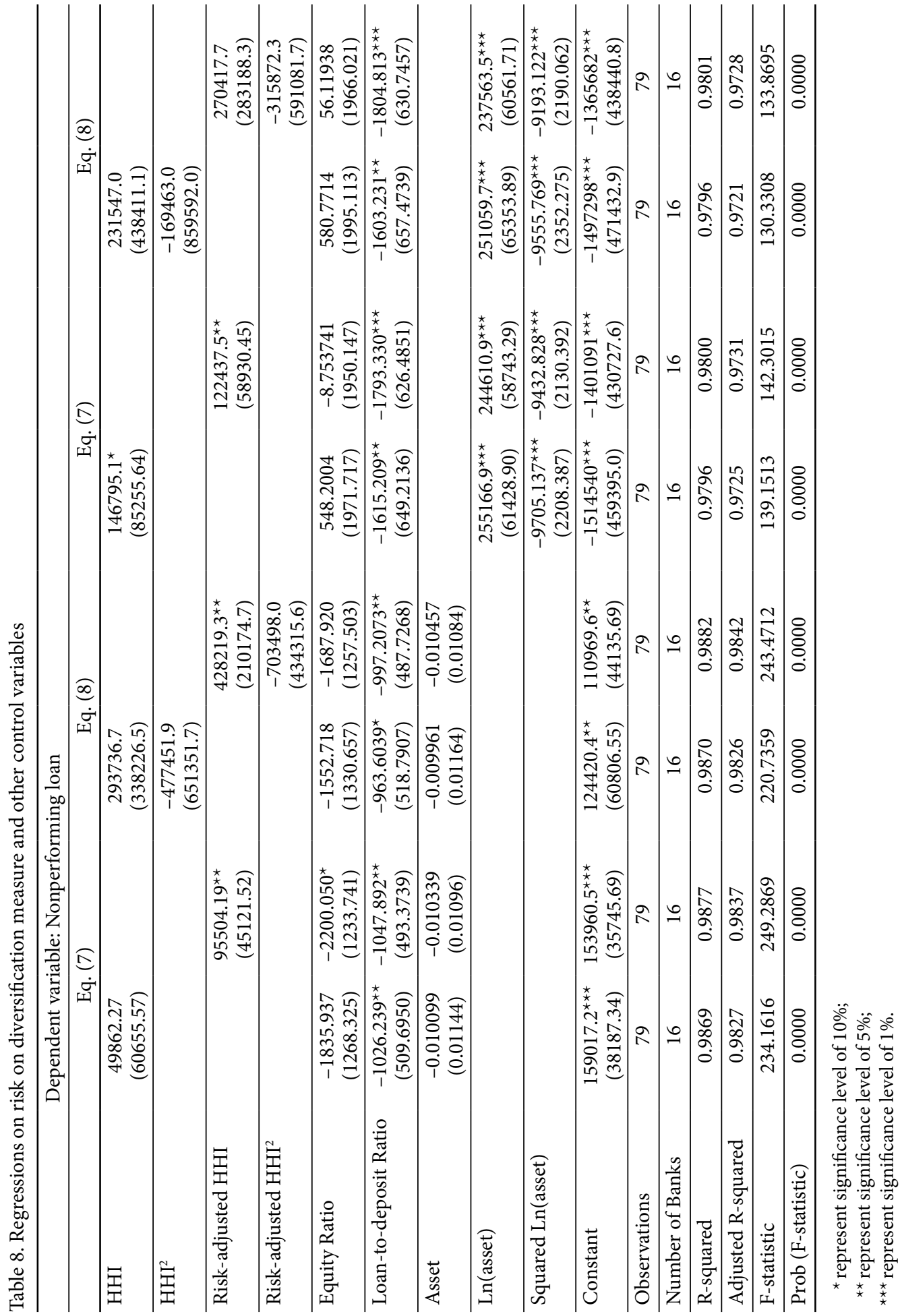




\section{Conclusions}

This paper investigates the effects of credit portfolio sectorial diversification on the banks' return and risk in Chinese banking sector. Panel data on 16 Chinese listed commercial banks during the 2007-2011 period is used for analysis. We construct a new diversification measure, taking systematic risk of different sectors into consideration by weighting them with their betas and compare the results to those of more conventional measure HHI.

We find that Chinese banks' credit loan portfolios are more diversified than all the countries' reported in previous studies, which may be due to strict regulation and supervision of our country.

Our main finding of empirical study is that sectorial diversification is associated with reduced return and also reduced risk at the same time, which contradicts existing findings in developed countries such as Italy and Germany, and also in emerging economies such as Brazil and Argentina. The reason to explain this may be that diversification may result in higher monitoring costs, which reduces the overall profits. At the same time, diversification helps offset the specific risks to achieve lower risks. The overall effects of Chinese sectorial diversification versus concentration on banks seems to be ambiguous and cannot be determined without taking a stand on what consists an efficient risk-return trade-offs.

Our analysis may also provide important implication for regulators and policy makers in other emerging economies.

From the aspect of regulators, it is more important to control risk to ensure financial stability than high profits of the banking industry. Therefore, we suggest setting limits on those sectors with higher systematic such as real estate to avoid second "subprime tragedy".

For those large banks, which are less vulnerable to risk, it is possible for them to be moderately focused especially on those they have expertise on to reduce cost in order to achieve higher return.

Another one of our main contributions is the newly constructed diversification measure, which takes systematic risk of sector into consideration. Risk-adjusted HHI performed well to capture the changes of sectors systematic risk and of exposures to sectors at the same time. We observe that there is a decreasing tendency of $\mathrm{HHI}$ in the five years in a row, which seems to indicate that credit portfolios are less concentrated. However, the year of 2011 witnessed a sharp increase in risk-adjusted HHI, suggesting that more exposures to sectors with higher systematic risk. The phenomenon should be noticed by the regulators, because an increased risk-adjusted HHI may be a sign of higher risk resulting in more nonperforming loan. This information, however, cannot be implied by traditional measure HHI.

\section{Acknowledgement}

This work has been partially supported by grants: Key Project (No. 71331005), Major International Joint Research Project (No. 71110107026), General Fund (No. 71071151) and Youth Fund (No. 71201143) from the National Natural Science Foundation of China, sponsorship from China Scholarship Council (CSC), and the CAS/SAFEA International Partnership Program for Creative Research Teams. 


\section{References}

Acharya, V.; Hasan, I.; Saunders, A. 2006. Should banks be diversified? Evidence from individual bank loan portfolios, Journal of Business 79(3): 1355-1412. http://dx.doi.org/10.1086/500679

Afzal, A.; Mirza, N. 2012. Size, diversification and risk: preliminary evidence from commercial banks in Pakistan, Pakistan Journal of Commerce and Social Sciences 6(2): 282-296.

Böve, R.; Pfingsten, A. 2008. Why do specialized banks succeed? An empirical investigation of the credit business of cooperative and savings banks. 28 p. http://dx.doi.org/10.2139/ssrn.1098421

Basel. 1991. Measuring and controlling large credit exposures. Reported by Basel Committee on Banking Supervision. 8 p.

Bebczuk, R.; Galindo, A. 2008. Financial crisis and sectoral diversification of Argentine banks, 1999-2004, Applied Financial Economics 18(3): 199-211. http://dx.doi.org/10.1080/09603100601018773

Berger, A. N.; Hasan, I.; Zhou, M. 2010. The effects of focus versus diversification on bank performance: evidence from Chinese banks, Journal of Banking and Finance 34(7): 1417-1435. http://dx.doi.org/10.1016/j.jbankfin.2010.01.010

De Jonghe, O.; Beck, T. 2013. Lending concentration, bank performance and systemic risk: exploring crosscountry variation [online], [cited 28 December 2013]. Available from Internet: https://23.21.67.251/ handle/10986/15830

Dempsey, M., et al. 2013. Stock market's assessment of bank diversification: evidence from listed public banks in South Asian countries. 48 p. http://dx.doi.org/10.2139/ssrn.2247775

Demyanyk, Y.; Van Hemert, O. 2011. Understanding the subprime mortgage crisis, Review of Financial Studies 24(6): 1848-1880. http://dx.doi.org/10.1093/rfs/hhp033

Diamond, D. W. 1984. Financial intermediation and delegated monitoring, The Review of Economic Studies 51(3): 393-414. http://dx.doi.org/10.2307/2297430

FDIC. 2007. An examination of the banking crises of the 1980s and early 1990s. Reported by Federal Deposit Insurance Corporation.

Fu, X. M.; Heffernan, S. 2009. The effects of reform on China's bank structure and performance, Journal of Banking and Finance 33(1): 39-52. http://dx.doi.org/10.1016/j.jbankfin.2006.11.023

García-Herrero, A.; Vázquez, F. 2013. International diversification gains and home bias in banking, Journal of Banking and Finance 37(7): 2560-2571. http://dx.doi.org/10.1016/j.jbankfin.2013.02.024

Hasan, I.; Wachtel, P.; Zhou, M. 2009, Institutional development, financial deepening and economic growth: evidence from China, Journal of Banking and Finance 33(1): 157-170. http://dx.doi.org/10.1016/j.jbankfin.2007.11.016

Hayden, E.; Porath, D.; von Westernhagen, N. 2007. Does diversification improve the performance of German banks? Evidence from individual bank loan portfolios, Journal of Financial Services Research 32(3): 123-140. http://dx.doi.org/10.1007/s10693-007-0017-0

Kamp, A.; Pfingsten, A.; Porath, D. 2005. Do banks diversify loan portfolios? A tentative answer based on individual bank loan portfolios, Journal of Financial Services Research 32: 132-140.

Li, J.; Feng, J.; Sun, X.; Li, M. 2012. Risk integration mechanisms and approaches in banking industry, International Journal of Information Technology \& Decision Making 11(6): 1183-1213. http://dx.doi.org/10.1142/S0219622012500320

Li, J.; Zhu, X.; Lee, C.-F.; Wu, D.; Feng, J.; Shi, Y. 2013. On the aggregation of credit, market and operational risks, Review of Quantitative Finance and Accounting. http://dx.doi.org/10.1007/s11156-013-0426-0

Lin, X.; Zhang, Y. 2009. Bank ownership reform and bank performance in China, Journal of Banking and Finance 33(1): 20-29. http://dx.doi.org/10.1016/j.jbankfin.2006.11.022

Markowitz, H. M. 1959. Portfolio selection: efficient diversification of investments. New York: John Wiley. 
McElligott, R.; Stuart, R. 2007. Measuring the sectoral distribution of lending to Irish non-financial corporates. Reported by Central Bank and Financial Services Authority of Ireland.

Mercieca, S.; Schaeck, K.; Wolfe, S. 2007. Small European banks: benefits from diversification?, Journal of Banking and Finance 31(7): 1975-1998. http://dx.doi.org/10.1016/j.jbankfin.2007.01.004

Pennathur, A. K.; Subrahmanyam, V.; Vishwasrao, S. 2012. Income diversification and risk: does ownership matter? An empirical examination of Indian banks, Journal of Banking and Finance 36(8): 2203-2215. http://dx.doi.org/10.1016/j.jbankfin.2012.03.021

Pfingsten, A.; Rudolph, K. 2002. German banks' loan portfolio composition: market orientation vs specialization. Reported by Institute for Kreditwesen.

Rhoades, S. A. 1993. The Herfindahl-Hirschman index, Federal Reserve Bulletin (March): 188-189.

Rossi, S. P. S.; Schwaiger, M. S.; Winkler, G. 2009. How loan portfolio diversification affects risk, efficiency and capitalization: a managerial behavior model for Austrian banks, Journal of Banking and Finance 33(12): 2218-2226. http://dx.doi.org/10.1016/j.jbankfin.2009.05.022

Sawada, M. 2011. How does the stock market value bank diversification? Empirical evidence from Japanese banks [online], [cited 28 December 2013]. Available from Internet: http://mpra.ub.uni-muenchen. de/id/eprint/45852.

Sharpe, W. F. 1963. A simplified model for portfolio analysis, Management Science 9(2): 277-293. http://dx.doi.org/10.1287/mnsc.9.2.277

Sharpe, W. F. 1964. Capital asset prices: a theory of market equilibrium under conditions of risk, The Journal of Finance 19(3): 425-442. http://dx.doi.org/10.2307/2977928

Stiroh, K. J.; Rumble, A. 2006. The dark side of diversification: the case of US financial holding companies, Journal of Banking and Finance 30(8): 2131-2161. http://dx.doi.org/10.1016/j.jbankfin.2005.04.030

Tabak, B. M.; Fazio, D. M.; Cajueiro, D. O. 2011. The effects of loan portfolio concentration on Brazilian banks' return and risk, Journal of Banking and Finance 35(11): 3065-3076. http://dx.doi.org/10.1016/j.jbankfin.2011.04.006

Tecles, P. L.; Tabak, B. M. 2010. Determinants of bank efficiency: the case of Brazil, European Journal of Operational Research 207(3): 1587-1598. http://dx.doi.org/10.1016/j.ejor.2010.06.007

Winton, A. 1999. Don't put all your eggs in one basket? Diversification and specialization in lending. University of Minnesota. $43 \mathrm{p}$.

Yibing CHEN. She is a PhD student from Research Centre on Fictitious Economy \& Data Science, Chinese Academy of Sciences. She got her Bachelor of Science in Information Science and Technology, and Dual Bachelor of Arts in English from University of International Relations, China in 2010. Her research interests include financial risk modeling and management, especially in banking system.

Yong SHI. PhD. He currently serves as the Executive Deputy Director, Research Centre on Fictitious Economy \& Data Science, Chinese Academy of Sciences. He has been the Union Pacific Chair of Information Science and Technology, College of Information Science and Technology, University of Nebraska, USA. He has published more than 21 books, over 200 papers in various journals. He is the Editor-in-Chief of International Journal of Information Technology and Decision Making (SCI indexed), and a member of Editorial Board for a number of academic journals. He has consulted or worked on business projects for a number of international companies and government agencies in data mining and risk management. His research interests include data science, multiple criteria decision making, credit scoring, credit risk analysis and big data applications.

Xianhua WEI. PhD. He currently is a Professor of Finance, School of Management, University of Chinese Academy of Sciences (UCAS), and Chief Executive Director of CAS-Reuters FRM laboratory. He also works as a Researcher at Research Centre on Fictitious Economy \& Data Science, Chinese Academy of 
Sciences. He worked at People's Bank of China, Branch in Changsha as a Director in Clearing Center for 13 years before he came to UCAS. His research papers have been published on many international and Chinese top journals. He has consulted or worked on business projects for a number of international companies and government agencies in risk management and investment strategy. His research areas include investment portfolio management, risk management and payment system management.

Lingling ZHANG. PhD. She currently is an Associate Professor at School of Management, University of Chinese Academy of Sciences. She also works as a Researcher at Research Centre on Fictitious Economy \& Data Science, Chinese Academy of Sciences. She was once a Visiting Scholar of Stanford University in the USA. She has published more than 40 papers in various journals. Currently, her research interests include data mining, intelligent knowledge management, and management information system. 